\title{
Pelaksanaan Alokasi Dana Desa Terhadap Manajemen Keuangan Desa dalam Meningkatkan Efektivitas Program Desa Sejahtera Mandiri Di Desa Cihambulu, Kec. Pabuaran, Kab. Subang
}

\author{
Nardi Sunardi ${ }^{1)}$ \& Rosa Lesmana ${ }^{2)}$ \\ ${ }^{1,2)}$ dosen Universitas Pamulang, email : dosen01030@unpam.ac.id
}

\section{ARTICLES \\ INFORMATION}

\section{ABSTRACT}

\section{JURNAL SEKURITAS \\ (Saham, Ekonomi, Keuangan dan Investasi ) \\ Vol.3, No.3, Mei 2020 \\ Halaman : $277-288$ \\ (c) LPPM \& Prodi Manajemen UNVERSITAS PAMULANG \\ ISSN (online) : 2581-2777 ISSN (print) : : 2581-2696}

\section{Keyword :}

Alokasi Dana Desa; Manajemen Keuangan Desa; Desa Sejahtera Mandiri

JEL. classification : Q15

\section{Contact Author :}

PRODI MANAJEMEN UNPAM JL.Surya Kencana No.1 Pamulang Tangerang Selatan Banten

Telp. (021) 7412566, Fax (021) 7412491 Email :

sekuritas@unpam.ac.id
Penelitian ini bertujuan dalam upaya dan strategi mewujudkan desa sejahtera mandiri di Desa Cihambulu. Dengan metode confirmatory analys factor menggunakan uji regression weight melalui perangkat Amos SPSS 23 . Responden adalah warga desa Cihambulu sebanyak 100 orang. Hasil penelitian menunjukkan Secara langsung Pelaksanaan Pengelolaan Dana Desa (PPDD) berpengaruh signifikan terhadap Manajemen Keuangan Desa (MKD) sebesar $5,144>1,96$, Manajemen Keuangan Desa (MKD) berpengaruh signifikan terhadap Efektivitas Program Desa Sejahtera Mandiri (EPDS) sebesar $4.288>1,96$, sedangkan secara tidak langsung Pelaksanaan Pengelolaan Dana Desa (PPDD) berpengaruh tetapi tidak signifikan terhadap Efektivitas Program Desa Sejahtera Mandiri (EPDS) sebesar 1.296.

This research aims to determine the efforts and strategies an independent prosperous village at desa Cihambulu. The confirmatory analysis method by using the regression weight test through Amos SPSS 23. Respondents were 100 Cihambulu citizen. The results showed that Village Fund Management (PPDD) had a significant effect on Village Financial Management (MKD) of 5.144> 1.96, Village Financial Management (MKD) had a significant effect on the Effectiveness of the Independent Prosperous Village Program (EPDS) of 4,288> 1, 96, Village Fund Management (PPDD) influences but not significantly to the Effectiveness of the Independent Prosperous Village Program (EPDS) of 1,296 


\section{A. PENDAHULUAN}

Pengelolaan keuangan desa seharusnya dilakukan dengan manajemen yang baik dana kuntabel karena dana yang masuk ke Desa bukanlah dana yang kecil, melainkan sangat besar untuk dikelola oleh sebuah Pemerintahan Desa. Dengan adanya kebijakan Dana Desa tersebut, maka dimensi manajemen pada pelaksanaan kebijakan Dana Desa tersebut perlu untuk diterapkan dengan baik karena menurut Nugroho (2014) kebijakan publik di dalamnya terjadi proses perancangan dan perencanaan; pelaksanaan melalui berbagai organisasi dan kelembagaan; serta dalam mendapatkan hasil yang baik, seharusnya ada pengendalian kebijakan publik dalam penerapannya. Dari pemaparan ahli tersebut jelas bahwa implementasi kebijakan yang baik di dalamnya dipengaruhi oleh proses manajemen yang baik pula untuk mencapai sesuatu yang diharapkan ketika pelaksanaan kebijakan sudah berjalan .

Menurut Ramdhani, \& Ramdhani (2017) menyatakan bahwa pelaksanaan kebijakan adalah penerapan suatu peraturan program, aksi dan tiindakan terta tindakan dalam suatu aturan yang menyatu pada suatu sistem tertentu. Sejak diimplementasikan kebijakan Alokasi Dana Desa (ADD) dan Dana Desa di tahun 2015, pemerintah daerah tidak terlepas dari berbagai masalah . Aziz (2016) menjabarkan ada dua masalah utama pelaksanaan dana desa, yakni: pertama, pemberian jumlah dana desa yang semakin besar setiap tahunnya akan tetapi tidak diimbangi dengan kapasitas dan kapabilitas sumber daya manusia (aparatur desa) di tingkat desa dalam pengelolaan keuangan desa. Kedua, minimnya keterlibatan masyarakat dalam perencanaan dan penyusunan APBDes dan RABDes, serta pengawasan penggunaan dana desa. Selain itu, Kementerian Keuangan Republik Indonesia (2016) mengevaluasi penyaluran dan penggunaan dana desa tahun anggaran 2018, dan mendapati beberapa masalah, yakni: pertama, sebagian daerah terlambat menetapkan Perbup/Perwali tentang pengalokasian dana desa. Kedua, terdapat keterpisahan antara perencanaan daerah dengan kebutuhan lokal dan perencanaan desa sehingga masih banyak desa yang belum mampu menyerap dana desa yang menjadi hak mereka padahal pemerintah telah memberikan panduan/pedoman tentang penggunaan Dana Desa dan Alokasi Dana Desa bagi para stakeholder pada tahun 2015 . (Noviyanti, Gamaputra, Lestari, \& Utami, 2018)

Permasalahan penyaluran dan pengalokasian dana desa tersebut juga dialami oleh kebanyakan desa-desa yang ada di Propinsi Jawa Barat, khususnya di Desa Cihambulu. Adapun masah pemanfaatan dana desa di Desa Cihambulu adalah aparatur pemerintah desa belum memiliki program prioritas pemberdayaan masyarakat di daerah mereka yang sejalan dengan prioritas penggunaan Dana Desa karena minimnya pengetahuan .

\section{A. KAJIAN LITERATUR}

\section{Pemerintah Desa}

Berdasarkan peraturan UU no. 6 tahun 2014, Desa adalah desa dan desa adat atau yang disebut dengan nama lain, selanjutnya disebut Desa, adalah kesatuan masyarakat hukum yang memiliki batas wilayah yang berwenang untuk mengatur dan mengurus urusan pemerintahan, kepentingan masyarakat setempat berdasarkan prakarsa masyarakat, hak asal usul, dan/atau hak tradisional yang diakui dan dihormati dalam sistem pemerintahan Negara Kesatuan Republik Indonesia . 


\section{Dana Desa}

Berdasarkan Peraturan Kemekeu Nomor 49 Tahun 2016 tentang cara pengelolaan, penyaluran, penggunaan, pemantauan, dan evaluasi Dana Desa, Dana Desa adalah dana yang bersumber dari Anggaran Pendapatan dan Belanja Negara yang diperuntukkan bagi desa yang ditransfer melalui Anggaran Pendapatan dan Belanja Daerah kabupaten/kota dan digunakan untuk membiayai penyelenggaraan pemerintahan, pelaksanaan pembangunan, pembinaan kemasyarakatan, dan pemberdayaan masyarakat .

\section{Pengelolaan Dana Desa}

Pengertian "pengelolaan dana desa" menurut Thomas (2013) adalah suatu proses atau suatu rangkaian pekerjaan yang dilakukan oleh serangkaian kelompok orang di dalamnya terdapat perencanaan, pengorganisasian, pelaksanaan dan pengawasan dengan memanfaatkan potensi yang ada dalam mencapai tujuan tertentu. Pengelolaan dana desa dalam Peraturan Presiden No 60 Tentang Dana Desa pasal 2 berbunyi Dana Desa dikelola secara tertib, taat pada ketentuan peraturan perundang-undangan, efisien, ekonomis, transparan, dan bertanggung jawab dengan memperhatikan rasa keadilan dan kepatutan serta mengutamakan kepentingan masyarakat setempat. Adapun dalam Peraturan Menteri Keuangan Nomor 49 tentang Tata Cara Pengalokasian, Penyaluran, Penggunaan, Pemantauan dan Evaluasi Dana Desa pasal 22 ayat 2 berbunyi pelaksanaan kegiatan yang dibiayai dari Dana Desa diutamakan dilakukan secara swakelola dengan menggunakan sumberdaya/bahan baku lokal, dan diupayakan dengan lebih banyak menyerap tenaga kerja dari masyarakat desa setempat .

\section{Pembangunan Desa}

Pengertian "Pembangunan Desa" berdasarkan Peraturan Kementrian Dalam Negeri Republik Indonesia Nomor 114 Tahun 2014 adalah upaya peningkatan kualitas hidup dan kehidupan untuk sebesar-besarnya kesejahteraan masyarakat desa. Perencanaan pembangunan desa adalah proses tahapan kegiatan yang diselenggarakan oleh Pemerintah Desa dengan melibatkan Badan Permusyawaratan Desa dan unsur masyarakat secara partisipatif guna pemanfaatan dan pengalokasian sumber daya desa dalam rangka mencapai tujuan pembangunan desa. Adapun tujuan pembangunan desa menurut UU no 6 tahun 2014 adalah meningkatkan kesejahteraan masyarakat desa dan kualitas hidup manusia serta penanggulangan kemiskinan melalui pemenuhan kebutuhan dasar, pembangunan sarana dan prasarana desa, pengembangan potensi ekonomi lokal, serta pemanfaatan sumber daya alam dan lingkungan secara berkelanjutan .

\section{Alokasi Dana Desa (ADD)}

Pengertian "Alokasi Dana Desa (ADD)" berdasarkan Peraturan Menteri Dalam Negeri Nomor 113 Tahun 2014 tentang Pedoman Pengelolaan Keuangan Desa, adalah dana perimbangan yang diterima kabupaten/kota dalam Anggaran Pendapatan dan Belanja Daerah kabupaten/kota setelah dikurangi Dana Alokasi Khusus. Berdasarkan PP Nomor 60 Tahun 2014 Dana Desa yang bersumber pada APBN bahwa Dana Desa adalah dana yang bersumber dari Anggaran Pendapatan dan Belanja Negara yang diperuntukkan bagi Desa yang ditransfer melalui Anggaran Pendapatan dan Belanja Daerah kabupaten/kota dan digunakan untuk membiayai penyelenggaraan pemerintahan, pelaksanaan pembangunan, pembinaan kemasyarakatan, dan pemberdayaan masyarakat. Bantuan Keuangan bersifat khusus dikelola dalam APBDesa tetapi tidak diterapkan dalam ketentuan penggunaan paling sedikit $70 \%$ (tujuh puluh perseratus) dan paling banyak $30 \%$ (tiga puluh perseratus). Belanja desa meliputi semua pengeluaran dari rekening desa yang merupakan kewajiban desa dalam1 (satu) tahun anggaran yang tidak akan diperoleh pembayarannya kembali oleh desa. Alokasi Dana Desa atau ADD adalah bagian keuangan Desa yang diperoleh dari Bagi 
Hasil Pajak Daerah dan Bagian dari Dana Perimbangan Keuangan Pusat dan Daerah yang diterima oleh kabupaten . (Nafidah \& Suryaningtyas, 2018

\section{Pelaksanaan Pengelolaan Dana Desa}

Menurut Yudianto Noverman (2018) menyatakan bahwa pelaksanaan pengelolaan Dana Desa adalah tindakan-tindakan yang dilakukan oleh individu-individu (dan kelompok) pemerintah dan swasta yang diarahkan pada pencapaian tujuan dan sasaran yang telah ditetapkan dari pengertian diatas dapat disimpulkan implementasi kebijakan terdiri dari tiga hal, yaitu (1) tujuan atau sasaran kebijakan, (2) aktivitas atau kegiatan pencapaian tujuan, dan (3) hasil kegiatan. Dalam pendekatan teori ini terdapat empat variabel yang mempengaruhi keberhasilan impelementasi suatu kebijakan , yaitu:

\section{Komunikasi}

Komunikasi digunakan supaya manajer atau yang membuat kebijakan dan para implementor akan semakin baik dalam melaksanakan setiap kebijakan yang akan diterapkan dalam masyarakat.

2. Sumber daya .

Dalam mengimlementasikan suatu kebijakan variabel yang paling dibutuhkan yaitu sumber daya, didalamnya umber daya finaial dan sumber daya manusia.

3. Disposisi

Disposisi adalah karekter atau watak yang dipunyai oleh implementator, seperti kejujuran, komitmen, serta sifat yang demokratis.

\section{Pengelolaan Keuangan Desa}

Berdasarkan Peraturan Presiden Nomor 43 Pasal 93 Tahun 2014 Pengelolaan Keuangan Desa adalah semua kegiatan yang meliputi 1) perencanaan, 2) penganggaran, 3) penatausahaan, 4) pelaporan dan 5) pertanggungjawaban, dan 6) pengawasan keuangan desa.

\section{Desa Sejahtera Mandiri (DSM)}

Menurut Rosa Lesmana (2019) "Desa Sejahtera Mandiri" adalah desa yang mampu mengelola kekuatan (asset dan potensi) yang dimiliki serta mampu memanfaatkan peluang yang ada dalam pengelolaan pembangunan untuk kesejahteraan warga desa. Desa yang bisa memenuhi kebutuhannya sendiri dan tidak semata tergantung dengan bantuan dari pemerintah dan pihak luar. Kalau ada bantuan sifatnya hanya stimulant atau perangsang saja .

Secara umum desa sejahtera mandiri dicirikan yaitu : mempunyai kemampuan desa mengurus dirinya sendiri dengan kekuatan yang dimilikinya, pemerintah desa desa memiliki kewenangan dalam mengatur dan mengelola pembangunan yang didukung oleh kemandirian dalam perencanaan, penganggaran dan pelaksanaan pembangunan (desa bisa merencanakan, menganggarkan dan melaksanakan pembangunan dan pengawas hasil pembangunan untuk kesejahteraan warga desanya), sistem pemerintahan desa menjunjung tinggi aspirasi dan partisipasi warga desa, termasuk warga miskin, perempuan, kaum muda, kaum difabel, penyandang masalah sosial dan warga yang termarginalkan lainnya dan sumber daya pembangunan dikelola secara optimal transparan dan akuntabel untuk dimanfaatkan sebaik-baiknya demi kesejahteraan sosial seluruh warganya . 


\section{B. METODOLOGI PENELITIAN}

Metode dalam penelitian ini digunakan adalah Confirmatory Analysis Factor dengan pendekatan kuantitatif. Diuji menggunakan uji regression weight melalui software Amos SPSS 23. Reponden dalam penelitian ini adalah warga Desa Cihambulu Kabupaten Subang, Jawa Barat sebanyak 100 orang.

Objek penelitian yaitudengan melihat kodisi objek secara objektif, Peneliti menetapkan variabel operasional disusun sehingga memudahkan dalam mengumpulkan dan menjaring data yang didapat dari responden sesuai dengan teori yang di dapat, konsep proposisi dan asumsi-asumsi dari variabel penelitian yang dibuat. Adapun variabel operasional penelitian disajikan pada

Tabel 1.

\section{Variabel Operasional Penelitian}

\begin{tabular}{|c|c|c|}
\hline Variabel & Dimensi & Indikator \\
\hline \multirow{10}{*}{$\begin{array}{l}\text { Variabel X } \\
\text { Pelaksanaan } \\
\text { Pengelolaan } \\
\text { Dana Desa } \\
\text { (Edward III } \\
\text { dalam-Agustino, } \\
\text { 2014) }\end{array}$} & \multirow[t]{3}{*}{ Komunikasi (KOM) } & Transmisi \\
\hline & & Kejelasan Kebijakan \\
\hline & & Konsistensi Kebijakan \\
\hline & \multirow[t]{3}{*}{ Sumberdaya (SDM) } & Staf atau Sumberdaya manusai \\
\hline & & Informasi \\
\hline & & Pemenuhan Fasilitas Staf atau SDM \\
\hline & \multirow[t]{2}{*}{ Disposisi (DPS) } & $\begin{array}{l}\text { Kesepakatan di Kalangan Pelaksana atau } \\
\text { Birokrat yang Telah Diangkat untuk } \\
\text { Melaksanakan Kebijakan }\end{array}$ \\
\hline & & Kemampuan Pelaksanaan \\
\hline & \multirow[t]{2}{*}{$\begin{array}{l}\text { Struktur Birokrasi } \\
\text { (BRK) }\end{array}$} & $\begin{array}{l}\text { Penggunaan Standar Operasional Prosedur } \\
\text { (SOP) }\end{array}$ \\
\hline & & Fragmentasi dalam Pertanggungjawaban \\
\hline \multirow{10}{*}{$\begin{array}{l}\text { Variabel Y } \\
\text { Manajemen } \\
\text { Keuangan } \\
\text { Desa } \\
\text { (PP Nomor } 43 \\
\text { Pasal 93 Tahun } \\
\text { 2014) }\end{array}$} & \multirow[t]{2}{*}{ Perencanaan (PLN) } & Pemilihan dan Penetepan Tujuan Organisasi \\
\hline & & $\begin{array}{l}\text { Kegiatan Persiapan Melalui Perumusan dan } \\
\text { Penetapan Keputusan }\end{array}$ \\
\hline & \multirow[t]{2}{*}{ Pelaksanaan (ACT) } & Pelaksanaan pengelolaan keuangan Desa \\
\hline & & $\begin{array}{llll}\begin{array}{l}\text { Implementasi } \\
\text { anggaran }\end{array} & \text { APBDesa } & \text { dalam } 1 \text { tahun } \\
\end{array}$ \\
\hline & \multirow[t]{2}{*}{ Penatausahaan (ADM) } & Tatalaksana Keuangan \\
\hline & & Pencatatan keuangan dengan baik dan benar \\
\hline & \multirow[t]{2}{*}{ Pelaporan (RPT) } & Pelaporan Tatalaksana Kegiatan \\
\hline & & $\begin{array}{l}\text { Penggunaan Anggaran yang Efektif } \\
\text { dan Efisien }\end{array}$ \\
\hline & \multirow{2}{*}{$\begin{array}{l}\text { Pertanggungjawaban } \\
\text { (LIAB) }\end{array}$} & Pertanggungjawaban \\
\hline & & ukuran kesesuaian pelayanan \\
\hline \multirow{7}{*}{$\begin{array}{l}\text { Variabel Z } \\
\text { Meningkatkan } \\
\text { Efektivitas } \\
\text { Program Desa } \\
\text { Sejahtera } \\
\text { Mandiri } \\
\text { (Indrawidjaja }\end{array}$} & \multirow{3}{*}{$\begin{array}{l}\text { Keterbukaan Kebijakan } \\
\text { Dasar,Tujuan dan } \\
\text { Rencana (OPN) } \\
\end{array}$} & Keterbukaan Kebijakan Dasar \\
\hline & & Keterbukaan Tujuan \\
\hline & & Keterbukaan Rencana \\
\hline & \multirow[t]{3}{*}{ Strategi (STR) } & Kejelasan Program \\
\hline & & Kejelasan Sasaran \\
\hline & & Kejelasan Tujuan \\
\hline & Pelaksanaan (PLKS) & Kesesuaian Perencanaan \\
\hline
\end{tabular}




\begin{tabular}{|l|l|l|}
\hline dalam & & Kesesuaian Pengorganisasian \\
\cline { 2 - 2 } Iskandar, 2016) & & Pengawasan \\
\cline { 2 - 3 } & Target Hasil (THS) & Pencapaian Tujuan \\
& & Kepuasan/ Keuntungan \\
\hline
\end{tabular}

Sumber : (Fahri, 2017)

\section{Kerangka Berpikir Penelitian}

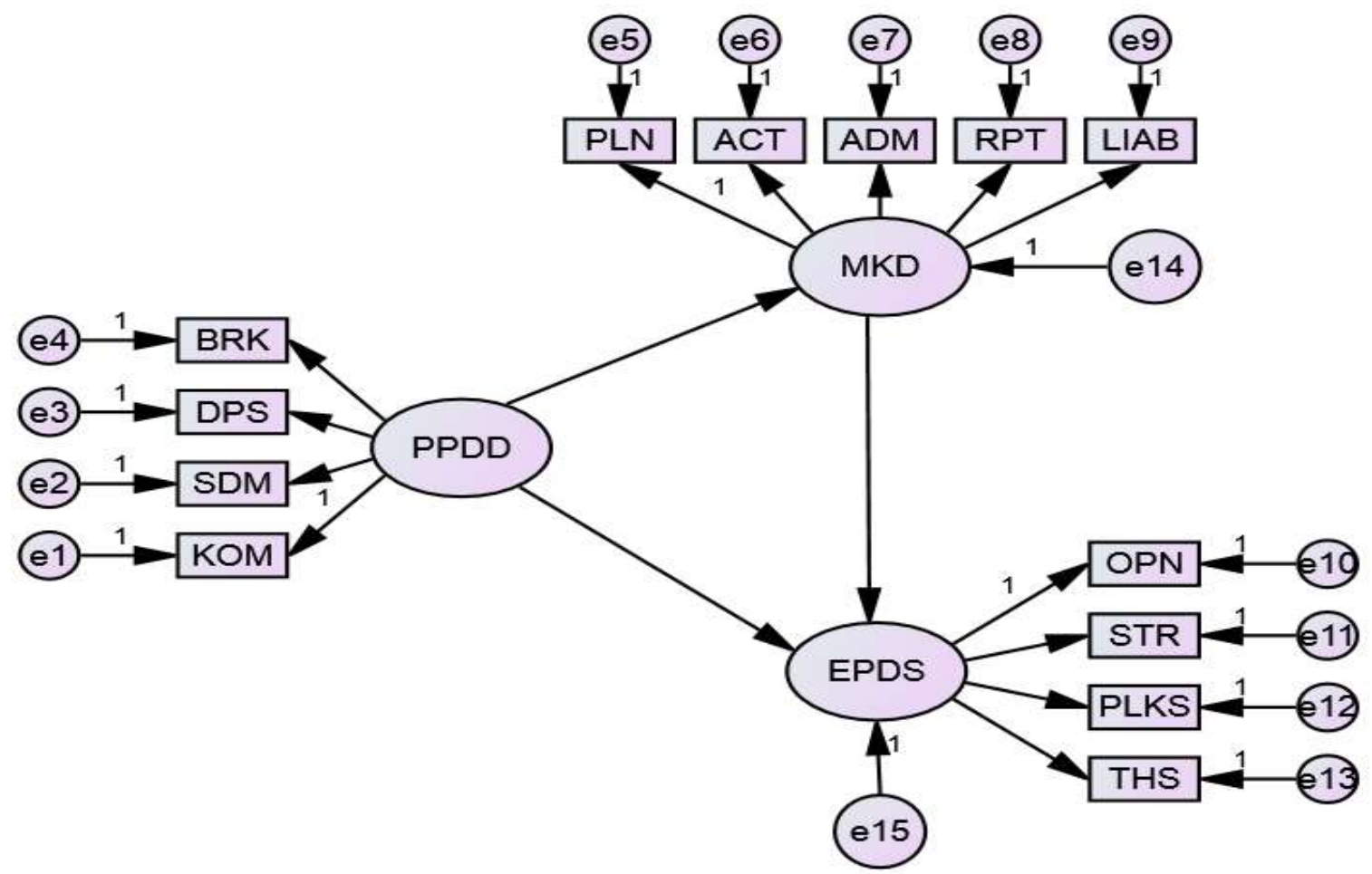

Gambar 1. Kerangka Berpikir

Berdasarkan kerangka ajuan diatas maka hipotesis yang diangkat sebagai berikut:

H1 : Pelaksanaan Pengelolaan Dana Desa berpengaruh terhadap Manajemen Keuangan Desa

H2 : Pelaksanaan Pengelolaan Dana Desa berppengaruh terhadap Meningkatkan Efektivitas Program Desa Sejahtera Mandiri.

H3 : Manajemen KeuanganDesa berengaruh terhadap Meningkatkan Efektivitas Program Desa Sejahtera Mandiri.

Berdasarkan isi pokok penelitian yang dilakukan, sasaran populasi dari penelitian ini adalah masyarakat dan aparatur desa yang telah Responden penelitian adalah di Desa Cihambulu, Kec. Pabuaran, Kab. Subang. 


\section{HASIL DAN PEMBAHASAN}

Lokasi penelitian di Kec. Pabuaran, Kab. Subang. Desa yang dikaji adalah Desa Cihambulu yang terletak di Kabupaten Subang. Sebagian besar penduduknya bermata pencaharian di sektor pertanian, perdagangan, pertukangan dan sektor informal lainnya.

\section{Uji Instrumen Penelitian}

Uji-Validitas Data

Tabel 2 ; Hasil Uji-Validitas Var. X, Y dan Z

\begin{tabular}{|l|l|c|c|c|}
\hline \multicolumn{1}{|c|}{ Variabel } & \multicolumn{1}{|c|}{ Indikator } & Hitung & R Tabel & $\begin{array}{c}\text { Kriteria } \\
\text { Validitas }\end{array}$ \\
\hline \multirow{4}{*}{$\begin{array}{l}\text { Variabel X } \\
\text { Pelaksanaan Pengelolaan }\end{array}$} & KOM (X1) & 0,464 & 0,198 & Valid \\
\cline { 2 - 5 } & KOM (X2) & 0,508 & 0,198 & Valid \\
\cline { 2 - 5 } & KOM (X3) & 0,509 & 0,198 & Valid \\
\cline { 2 - 5 } & SDM (X4) & 0,629 & 0,198 & Valid \\
\cline { 2 - 5 } & SDM (X5) & 0,462 & 0,198 & Valid \\
\cline { 2 - 5 } & SDM (X6) & 0,571 & 0,198 & Valid \\
\cline { 2 - 5 } & DPS (X7) & 0,552 & 0,198 & Valid \\
\cline { 2 - 5 } & DPS (X8) & 0,647 & 0,198 & Valid \\
\cline { 2 - 5 } & BRK (X9) & 0,638 & 0,198 & Valid \\
\cline { 2 - 5 } & BRKX10 & 1,000 & 0,198 & Valid \\
\hline
\end{tabular}

\begin{tabular}{|l|l|c|c|c|}
\hline \multicolumn{1}{|c|}{ Variabel } & \multicolumn{1}{|c|}{ Indikator } & $\begin{array}{c}\text { R } \\
\text { Hitung }\end{array}$ & R Tabel & $\begin{array}{c}\text { Kriteria } \\
\text { Validitas }\end{array}$ \\
\hline \multirow{5}{*}{ Variabel $Y$} & PLN (Y1) & 0,455 & 0,198 & Valid \\
\cline { 2 - 5 } & PLN (Y2) & 0,348 & 0,198 & Valid \\
\cline { 2 - 5 } & ACT (Y3) & 0,637 & 0,198 & Valid \\
\cline { 2 - 5 } & ACT (Y4) & 0,398 & 0,198 & Valid \\
\cline { 2 - 5 } & ADM (Y5) & 0,327 & 0,198 & Valid \\
\cline { 2 - 5 } & ADM (Y6) & 0,395 & 0,198 & Valid \\
\cline { 2 - 5 } & RPT (Y7) & 0,468 & 0,198 & Valid \\
\cline { 2 - 5 } & RPT (Y8) & 0,443 & 0,198 & Valid \\
\cline { 2 - 5 } & LIAB (Y9) & 0,610 & 0198 & Valid \\
\cline { 2 - 5 } & LIAB (Y10) & 0,1000 & 0,198 & Valid \\
\hline
\end{tabular}

\begin{tabular}{|l|l|c|c|c|}
\hline \multicolumn{1}{|c|}{ Variabel } & Indikator & $\begin{array}{c}\text { R } \\
\text { Hitung }\end{array}$ & R Tabel & $\begin{array}{c}\text { Kriteria } \\
\text { Validitas }\end{array}$ \\
\hline \multirow{4}{*}{$\begin{array}{l}\text { Variabel Z } \\
\text { Meningkatkan Efektivitas }\end{array}$} & OPN (Z1) & 0,524 & 0,198 & Valid \\
\cline { 2 - 5 } & OPN (Z2) & 0,447 & 0,198 & Valid \\
\cline { 2 - 5 } & STR (Z3) & 0,385 & 0,198 & Valid \\
\cline { 2 - 5 } & STR (Z4) & 0,461 & 0,198 & Valid \\
\cline { 2 - 5 } & PLKS (Z5) & 0,622 & 0,198 & Valid \\
\cline { 2 - 5 } & PLKS (Z6) & 0,689 & 0,198 & Valid \\
\cline { 2 - 5 } & PLKS (Z7) & 0,433 & 0,198 & Valid \\
\cline { 2 - 5 } & THS (Z8) & 0,682 & 0,198 & Valid \\
\cline { 2 - 5 } & THS (Z9) & 0,1000 & 0198 & Valid \\
\hline
\end{tabular}

Sumber: Output SPSS 23 
Data tabel diatas menunjukkan bahwa semua indikator penelitian dikatagorikan nilainya valid dengan nilai R-hitung lebih besar (>) dari nilai R-Tabel maka Analisa berikutnya dapat dilanjutkan.

\section{Uji-Reliabilitas}

Tabel 4 ; Uji-Reliabilitas

\begin{tabular}{|l|c|c|}
\hline \multicolumn{1}{|c|}{ Variabel latent } & $\begin{array}{c}\text { Koefisien Raliabilitias } \\
\text { Cronbach's Alpha }\end{array}$ & Kreteria Uji \\
\hline Pelaksanaan Pengelolaan Dana Desa & 0,921 & Realiabel \\
\hline Manajemen Keuangan Desa & 0.897 & Realiabel \\
\hline $\begin{array}{l}\text { Meningkatkan Efektivitas Program } \\
\text { Desa Sejahtera Mandiri }\end{array}$ & 0,944 & Realiabel \\
\hline
\end{tabular}

Sumber: Output SPSS 23

Dari table diatas dapat dilihat nilai alpha cronbach kepuasan wisatawan 0,920 $>0,60$ dan loyalitas wisatawan 0,905 > 0,60 kedua variabel berdasarkan kriteria uji , dikatakan reliabel

\section{Uji-Goodness - of fit Indices}

Tabel 5 ; Evaluasi Kriteria Goodness-offit Indices

\begin{tabular}{|l|c|c|c|}
\hline \multicolumn{1}{|c|}{ Kreteria } & Hasil Model & Nilai Kritis & $\begin{array}{c}\text { Evaluasi } \\
\text { Model }\end{array}$ \\
\hline Chi-Square $X^{2}$ CMIN & 42.173 & $\begin{array}{c}\text { Besar, } X^{2} \\
\text { dengan } \mathrm{df}=1 \\
\text { adalah } 0,997\end{array}$ & Baik \\
\hline Probability (P) & 0.744 & $\geq 0.05$ & Baik \\
\hline$X^{2}$ Relatif (CMIN/DF) & 0.861 & $\leq 2.0$ & Baik \\
\hline GFI & 0.934 & $\geq 0.90$ & Baik \\
\hline AGF & 0.878 & $\geq 0.90$ & $\begin{array}{c}\text { Kurang } \\
\text { Baik }\end{array}$ \\
\hline TLI & 1.020 & $\geq 0.95$ & Baik \\
\hline CFI & 1.000 & $\geq 0.95$ & Baik \\
\hline RMSEA & 0.000 & $\leq 0.08$ & Baik \\
\hline
\end{tabular}

Sumber : Pengolahan data Amos SPSS

Confirmatory Factor Analysis pada measurement model dalam penelitian ini menunjukan model yang baik, dimana nilai GFI lebih tinggi dari tingkat yang disarankan 0.90; Sebagian besar hasil pengujian dengan kriteria yang baik

\section{Hasil Uji-Regression Weight}

Tabel 6 Regression Weight (Loading Factor) Measurement Model

\begin{tabular}{|lcc|ccccc|}
\hline \multicolumn{2}{|c|}{ Regression Weight } & Estimate & S.E. & C.R. & P & Label \\
\hline MKD & $<---$ & PPDD & .553 & .108 & 5.144 & $* * *$ & \\
EPDS & $<---$ & MKD & 1.522 & .355 & 4.288 & $* * *$ & \\
EPDS & $<---$ & PPDD & .296 & .228 & 1.296 & .195 & \\
KOM & $<---$ & PPDD & 1.000 & & & &
\end{tabular}




\begin{tabular}{|lcc|ccccc|}
\hline \multicolumn{2}{|c|}{ Regression Weight } & Estimate & S.E. & C.R. & P & Label \\
\hline SDM & $<---$ & PPDD & .969 & .181 & 5.352 & $* * *$ & \\
DPS & $<--$ & PPDD & .634 & .100 & 6.305 & $* * *$ & \\
BRK & $<--$ & PPDD & .735 & .132 & 5.554 & $* * *$ \\
PLN & $<--$ & MKD & 1.000 & & & \\
ACT & $<---$ & MKD & 1.099 & .151 & 7.299 & $* * *$ \\
ADM & $<--$ & MKD & 1.000 & .128 & 7.835 & $* * *$ \\
RPT & $<--$ & MKD & 1.284 & .218 & 5.882 & $* * *$ \\
LIAB & $<--$ & MKD & 1.038 & .171 & 6.056 & $* * *$ \\
OPN & $<--$ & EPDS & 1.000 & & & \\
STR & $<--$ & EPDS & .830 & .108 & 7.700 & $* * *$ \\
PLKS & $<--$ & EPDS & .586 & .094 & 6.216 & $* * *$ \\
THS & $<---$ & EPDS & -.067 & .088 & -.763 & .446 \\
\hline
\end{tabular}

Sumber : Pengolahan dengan Amos SPSS

Tabel diatas menunjukan hasil regresi yang diperoleh melalui hasil perhitungan dengan menggunakan Amos SPSS 23, dari hasil regersi diperoleh hampir semua pengaruh memiliki nilai $P$ lebih kecil $\leq 0,05$ dan Critical Ratio $\geq 1,96$ artinya mendukung hipotesis.



Gambar 2 Hasil Pengolahan Data Amos SPSS 23 


\section{KESIMPULAN}

\section{Kesimpulan}

Berdasarkan hasil Koefisien jalur pengaruh langsung (direct effect) Pelaksanaan Pengelolaan Dana Desa (PPDD) terhadap Manajemen Keuangan Desa (MKD) sebesar $5,144 \geq 1,96$, Pengaruh langsung Manajemen Keuangan Desa (MKD) terhadap Efektivitas Program Desa Sejahtera Mandiri (EPDS) sebesar $4.288 \geq 1,96$, sedangkan pengaruh tidak langsung (indirect effect) Pelaksanaan Pengelolaan Dana Desa (PPDD) terhadap Efektivitas Program Desa Sejahtera Mandiri (EPDS) sebesar 1.296. Dari analisis ini, maka dapat disimpulkan bahwa Pelaksanaan Pengelolaan Dana Desa (PPDD) berpengaruh signifikan terhadap Manajemen Keuangan Desa (MKD), dan Manajemen Keuangan Desa (MKD) berpengaruh signifikan terhadap Efektivitas Program Desa Sejahtera Mandiri (EPDS) sedangkan secara tidak langsung Pelaksanaan Pengelolaan Dana Desa (PPDD) berpengaruh tetapi tidak signifikan terhadap Efektivitas Program Desa Sejahtera Mandiri (EPDS).

\section{Saran}

Berdasarkan rata - rata jawaban responden terhadap kuisioner terdapat beberapa item dengan nilai rata - rata paling rendah yaitu dari 100 responden menjawab rata - rata dengan skor 3,03 pada item Indikator Pelaksanaan, baik dalam perencanaan pelaksanaan program, strategi dan pengorganisasian program dan pengawasan terhadap pelaksaksanaan program dari unsur terkait. Atau secara keseluruhan proses manajemen dalam pelaksanaan masih kurang baik, diharapkan penelitian ini dapat menjadi masukan bagi aparat pemerintah desa Cihambulu, Pabuaran, Subang, Jawa Barat sehingga kedepan pemerintah desa dapat menjalankan proses manajemen dengan baik terutama pada proses pelaksanaan program desa guna terwujud Desa Sejahterah Mandiri .

\section{DAFTAR PUSTAKA}

Agustiani, Y. S., \& Solihat, Y. (2018). Partisipasi Masyarakat Dalam Pembangunan Insfrastuktur Desa di Desa Cihambulu Kecamatan Pabuaran Kabupaten Subang. Jurnal Politikom Indonesiana VOL. 3 NO. 2, 187-195.

Agustino, L. (2014). Dasar-Dasar Kebijakan Publik. Bandung: Alfabeta.

Aziz, Nyimas Latifah L. (2016). "Otonomi Desa dan Efektivitas Dana Desa.Jurnal Penelitian Politik, 13(2). Jakarta: Peneliti Pusat Penelitian Politik",

Boedijono, Wicaksono, G., \& Puspita, Y. (2019). "Efektifitas Pengelolaan Dana Desa Untuk Pembangunan dan Pemberdayaan Masyarakat Desa di Kabupaten Bondowoso". Jurnal Riset Manajemen dan Bisnis (JRMB) Fakultas Ekonomi UNIAT, 9 - 20.

Fahri, L. N. (2017). "Pengaruh Pelaksanaan Kebijakan Dana Desa terhadap Manajemen Keuangan Desa dalam Meningkatkan Efektivitas Program Pembangunan Desa". Jurnal Publik, Vol. 11; No. 01; 75-88.

Guitman LJ, Z. C. (2012). "Principles of Managerial Financial Global Edition 13th Edition". England:: Person Education Limited 2012. 
Gujarati Damodar N, F. D. (2013). "Basic Econometrics, 5th Edition. Diterjemahkan oleh: Eugenia Mardanugraha", Sita Mardani, Carlos Mangunsong. (2013). Dasar-dasar Ekonometrika. Jakarta:: Salemba Empat.

Haryanto, Tri. 2007. Menuju Mayarakat Swadaya dan Swakelola. Klaten: Cempaka Putih

Houston, B. \&. (2013). "Essential of Financial Management. Original edition first published by Cengage Learning 2007,Diterjemahkan oleh: Ali Akbar Yulianto. 2011".

Kehik, B. S., \& Mael, M. Y. (2017). Analisis Pengelolaan Alokasi Dana Desa dalam Peningkatan Perekonomian Masyarakat Petani di Desa Usapinonot. Jurnal Agribisnis Lahan Kering, 59-62.

Kementerian Keuangan Republik Indonesia. (2016). Kebijakan Pengalokasian dan Penyaluran Dana Desa Tahun 2017. Workshop Penyusunan Rancangan Peraturan Kepala Daerah mengenai Tata Cara Penghitungan Pembagian dan Penetapan Rincian Dana Desa TA 2017.

Lesmana, R., Sunardi, N., Hasbiyah, W., Tumanggor, M., \& Susanto, S. (2019). Manajemen Alokasi Dana Desa dalam Upaya dan Strategi Mewujudkan Desa Sejahtera Mandiri di Desa Cihambulu, Kec. Pabuaran, Kab. Subang, Jawa Barat. Jurnal Abdi Masyarakat Humanis, 1(1).

Lesmana, R., Sunardi, N., Kartono, K., Rudy, R., \& Sumiaty, R. Y. (2020). Implementasi Manajemen dalam Meningkatkan Minat Baca Warga Desa Cihambulu, Kec. Pabuaran, Kab. Subang, Jawa Barat. Jurnal Abdi Masyarakat Humanis, 1(2).

Nafidah, L. N., \& Suryaningtyas, M. (2018). "Akuntabilitas pengelolaan alokasi dana desa dalam upaya meningkatkan pembangunan dan pemberdayaan masyarakat Desa Dapurkejambon. Jurnal Bisnis dan Manajemen Islam, 213-239".

Noverman, Y. (2018). "Analisis Kesesuaian Pengelolaan Dana Desa dengan Peraturan Perundang-Undangan (Studi Kasus di Nagari Bukit Bual Kabupaten Sijunjung). JAKPP (Jurnal Analisis Kebijakan dan Pelayanan Publik), 68-81".

Noviyanti, Gamaputra, G., Lestari, Y., \& Utami, D. A. (2018). Pengidentifikasian Pendapatan dan Prioritas Penggunaan Dana Desa. PUBLISIA: Jurnal IImu Administrasi Publik Volume 3, Nomor 2, 112-121.

Nurcholis, H. (2017). Pertumbuhan dan Penyelenggaraan Pemerintahan Desa. Jakarta: Erlangga.

Peraturan Menteri Dalam Negeri Nomor 113 Tahun 2014 tentang Pengelolaan Keuangan Desa.

Peraturan Menteri Dalam Negeri nomor 114 tahun 2014 tentang Pedoman Pembangunan Desa.

Peraturan Menteri Keuangan No. 32 Tahun 2018 tentang Standar Biaya Masukan Tahun Anggaran 2019

Peraturan Presiden Nomor. 43 Tahun 2014.

Rahayu, D. (2017). "Strategi Pengelolaan Dana Desa untuk Meningkatkan Kesejahteraan Masyarakat Desa Kalikayen Kabupaten Semarang. Economics Development Analysis Journal," 107-116. 
Ramdhani, A., \& Ramdhani, M. A. (2017). Konsep Umum Pelaksanaan Kebijakan Publik. Jurnal Publik, 11(1), 1-12.

Rudy, R., Sunardi, N., Kartono, K., Sudarso, A. P., \& Lutfy, A. M. (2019). Pengelolaan Keuangan Masyarakat untuk Mewujudkan Desa Sejahtera Mandiri di Desa Cihambulu, Kec. Pabuaran Kab. Subang, Jawa Barat. Jurnal Abdi Masyarakat Humanis, 1(1).

Sarwani, S., Sunardi, N., AM, E. N., Marjohan, M., \& Hamsinah, H. (2020). Penerapan IImu Manajemen dalam Pengembangan Agroindustri Biogas dari Limbah Kotoran Sapi yang Berdampak pada Kesejahtraan Masyarakat Desa Sindanglaya Kec. Tanjungsiang, Kab. Subang. Jurnal Abdi Masyarakat Humanis, 1(2).

Sugiyono. (2013). Memahami Penelitian Kualitatif. Bandung: Alfabeta

Sumarsono, S. (2010). Manajemen Keuangan Pemerintahan. Yogyakarta: Graha IImu.

Sunardi, N. (2019). Mekanisme Good Corporate Governance Terhadap Nilai Perusahaan Dengan Leverage Sebagai Variabel Intervening Pada Perusahaan Manufaktur Yang Terdaftar Di Bursa Efek Indonesia Tahun 2012-2018. JIMF (Jurnal IImiah Manajemen Forkamma), 2(3).

Sunardi, N. (2019). Relevansi Intelectual Capital terhadap Harga dan Retun Saham di Industri Perbankan Pemerintah di Indonesia. JIMF (Jurnal IImiah Manajemen Forkamma), 3(1).

Thomas. (2013). Pengelolaan Alokasi Dana Desa Dalam Upaya Meningkatkan Pembangunan di Desa Sebawang Kecamatan Sesayap Kabupaten Tana Tidung.

Undang-Undang Nomor 23 Tahun 2014 tentang "Pemerintah Daerah".

Undang-Undang Nomor 33 Tahun 2004 tentang "Perimbangan Keuangan antara Pemerintah Pusat dan Daerah".

Undang-Undang Nomor 6 Tahun 2014 tentang Desa. 